\title{
Transformation Adaptation of Farmers to Forest Management Based on Social Forestry Policy in Various Types of Forest, Malang, Indonesia
}

\author{
Medea Rahmadhani Utomo*, Mangku Purnomo, Novil Dedy Andriatmoko, \\ Sarahnanda Nur Lestari
}

\author{
Departement of Socioeconomic, Agriculture Faculty, Brawijaya University \\ *Corresponding author. Email: medea@ub.ac.id
}

\begin{abstract}
Transformation adaptation arises due to increased deforestation and how communities around the forest adapt to sustain their lives. Uncertainty over forest area control can hinder the effectiveness of forest management. In order to accommodate the functions of protection and use of the economy in a balanced, the government has issued a policy on forest resource management since the Old Order era developed into the New Order era to the present era. This study aims to describe the development of community adaptation to changes in forest management patterns in Wajak District. The research was conducted in Wajak District, Malang Regency. The stages of data analysis in this qualitative research were carried out with interactive techniques, including data reduction, data presentation, conclusion drawing or verification. Researchers use two techniques, including triangulation (combined) from the type of source and technique triangulation. Based on the results of the study, it was found that the transformation of forest management patterns based on each transition period included planting, maintenance, profit sharing collection, processing and marketing of forest products, as well as the form of cooperation policies with Forest Village Community or Masyarakat Desa Hutan (MDH) in Wajak District. Transformation adaptation of community in forest areas changes in line with the Social Forestry policy. At present, this transformation has an impact that the community feels in terms of social, economic, and environmental aspects. Other impacts include open access to community development and empowerment programs, diverse community livelihoods, and environmental conservation in the forest.
\end{abstract}

Keywords: Adaptation; Transformation; Social Forestry; Forest Management.

\section{INTRODUCTION}

Forests are natural resources that have an essential role in regulating the balance of the environment and the community's survival around the forest [1]. Data from the Directorate General of Forestry Planning and Environmental Management shows that the results of monitoring the area of forested land throughout Indonesia in 2019 were 94.1 million ha or $50.1 \%$ of the total land area of Indonesia [2].

Most Indonesians are economically dependent on the potential of forest areas. Twenty-five thousand eight hundred villages, or $34.1 \%$ of the total 74,954 villages throughout Indonesia, are directly adjacent to forest areas. The 22.1 million hectares terrestrial conservation area is surrounded by 6,381 villages, with most of the population dependent on natural resources to meet their daily needs [3]. Meanwhile, the area of forested land in East Java is 1,361,146 ha consisting of protected forests, nature reserves and nature conservation, and permanent production forests [4].

Uncertainty over forest area control can hinder the effectiveness of forest management [5]. This can affect local communities' survival in forest areas, including the private sector and the government. For example, Possumah et al. [6] stated that the location of farmers' arable land in forest areas without a utilization permit would affect the potential for natural resources, both timber and non-timber, to be lower. The social forestry program appears to accommodate the function of protection and economic use in a balanced way and 
ensure the availability of land and community access to forest areas [7].

Social forestry as a forest management policy has the side and the potential to involve the community around the forest area to empower existing forest resources [8]. This is supported by developing the theory of Community Based Natural Resource Management, collective management of ecosystems to improve human welfare [9]. There are primary objectives of Community Based Natural Resource Management: poverty alleviation, conservation of natural resources, and good governance [1].

The Minister of Environment and Forestry Regulation No. P.39/Menlhk/Setjen/Kum.1/6/2017 concerning social forestry in the working area of Perum Perhutani. Social Forestry Schemes The development of social forestry policies in Indonesia until the issuance of the Minister of Environment and Forestry P.83/2016 concerning Social Forestry stipulates five social forestry schemes, namely Village Forests, Community Forests, Community Plantation Forests, Forestry Partnerships, and Customary Forests. In order to support the scheme to work to accommodate communities around the forest, a Joint Community Forest Management Program / Pengelolaan Hutan Bersama Masyarakat (PHBM) was prepared [8].

The existence of forest area management policies through the PHBM program that involves the community can cause profound and long-term social shifts or changes [10]. Social shifts, in this case, will provide a new pattern of adjustment for society to adapt, which can be observed in political, personal, and practical aspects. Adaptation transformation is an adaptation that changes the function, structure, identity and feedback that characterizes a system or process [11]. Enabling involves replacing existing ones with new systems and processes [12].

Wajak Subdistrict, Malang Regency is one of the areas whose land ownership and control patterns are based on Malang Regency Government Regulation Number 3 of 2010 concerning Regency Spatial Planning, where Wajak Subdistrict is included in the cultivation area and economic strategy. Furthermore, as a cultivation area and located west of the foot of Mount
Semeru, the Wajak District area is within the scope of a forest area managed by Perum Perhutani Malang [13]

The majority of the population work as farmers and ranchers [14]. This does not rule out the possibility that the community around the forest will take part in utilizing forest products. Bambang Village, Patokpicis and Sumberputih in Wajak District. For example, such conditions, of course, also trigger conflicts between farmers or Perhutani, according to research conducted by Subarna [15].

To find out the development of forest management patterns by farmers in the villages of Bambang, Patokpicis and Sumberputih, researchers are interested in conducting research related to the transformation of adaptation of forest management patterns by farmers working on forest land to social forestry policies in Wajak District, Malang Regency [16].

Based on this case, the researchers are interested in following up the research objectives, include 1) Identifying the adaptation transformation of farmers in the use of forest areas after following the Social Forestry Policy, 2) Knowing the factors causing the sale of village forest management rights to farmers outside the village. 3) Analyzing farmers' responses to impacts on forest area utilization.

\section{MATERIALS AND METHODS}

The informant determination technique used in this research is purposive sampling and snowball sampling. Primary data collection techniques consist of in-depth interviews and observation. Secondary data collection techniques were carried out using literature studies and research documentation

To see the transformation of farmers towards changes in forest tenure policies, the analytical method uses historical analysis or analysis of sequences of events [17]. Then also carried out data analysis with interactive techniques according to Miles and Humberman [18], including data reduction, data presentation, drawing conclusions or verification. Data reduction is selecting, focusing, simplifying and transforming data that emerges from the observation notes [19]. Presentation of data is a collection of 
structured information that allows concluding or taking action.

\section{RESULTS AND DISCUSSION}

\subsection{Transformation of Forest Management Patterns}

Agricultural development activities in rural areas can contribute to food security and poverty alleviation efforts [20]. The period of the New Order government, which regulates policies related to the Basic Provisions of Forestry in its implementation, emphasizes that forest exploitation is carried out based on the principle of forest sustainability and remains focused on increasing the production of forest products.

Table 1. The Process of Transforming Forest Management Patterns in Bambang Village

\begin{tabular}{|c|c|}
\hline Transition period & Transformation \\
\hline $\begin{array}{l}\text { Reformation Era } \\
\text { (New Order era } \\
1966-1998)\end{array}$ & $\begin{array}{l}\text { 1. Forest production plants are mostly Sengon } \\
\text { 2. The productivity of the plants under the stand is still good without having to use any } \\
\text { additional fertilizer. } \\
\text { 3. Revenue sharing is set at } 75 \% \text { Perhutani and } 25 \% \text { for the community } \\
\text { 4. Perhutani area land management rights system is limited to a maximum of } 3 \text { years } \\
\text { 5. Forest society does not have written evidence of managed land } \\
\text { 6. High cases of illegal logging } \\
\text { 7. Determination of free land plots based on who can get it fast and who can afford it }\end{array}$ \\
\hline $\begin{array}{l}\text { Reformation Era } \\
(1999-2019)\end{array}$ & $\begin{array}{l}\text { 1. Timber forest production plants are mostly pine and mahogany } \\
\text { 2. Forest society uses organic fertilizers derived from dirt and chemicals to increase } \\
\text { crop productivity } \\
\text { 3. The community is not subject to profit sharing } \\
\text { 4. The form of the institution that supervised the LMDH was initially changed to } \\
\text { LKDPH. } \\
\text { 5. The existence of a program for the welfare of MDH by Perhutani is known as } \\
\text { PHBM. } \\
\text { 6. Perhutani area land management rights system without time limit } \\
\text { 7. Forest society does not have written evidence of managed land } \\
\text { 8. There is a pine tree tapping program for Forest society } \\
\text { 9. Perhutani regulates the determination of the area and location of the Forest society } \\
\text { land plots fairly }\end{array}$ \\
\hline $\begin{array}{l}\text { Reformation era - } \\
\text { Present (2019-2021) }\end{array}$ & $\begin{array}{l}\text { 1. Forest production plants turn to annual fruit crops such as coffee, durian, avocado, } \\
\text { breadfruit, and crystal guava. } \\
\text { 2. Subsidy for seedlings and seeds for plants understands for smallholders from } \\
\text { conservation programs UP UPSA, CCCD, and BPDAS. } \\
\text { 3. Forest society began to be interested in learning organic farming (bokashi fertilizer) } \\
\text { 4. The community is not subject to profit-sharing by Perhutani } \\
\text { 5. Form an institution that oversees LKDPH and KTH } \\
\text { 6. The existence of PHBM (Perhutani) and Social Forestry (Government) policy } \\
\text { programs } \\
\text { 7. The land management rights system for the Perhutani area is limited for } 35 \text { years } \\
\text { following the Social Forestry policy. } \\
\text { 8. Forest society has written evidence of managed land in an official certificate that } \\
\text { can be used as collateral. } \\
\text { 9. There is a collaboration with Bank BNI that residents can use to apply for loans. }\end{array}$ \\
\hline
\end{tabular}

Source: Primary data processed by researchers (2021)

Based on this, the transformation of forest management patterns will be discussed in depth based on each transition period, including planting, maintaining, collecting profit sharing, processing 
and marketing forest products, as well as how to form a policy of cooperation with Forest Village Communities (MDH) in Bambang Village.

\subsubsection{Pre-Reformation Land Management Pattern}

The agricultural system practised by Forest society on Perhutani land areas can be described through land management activities, planting plants understands, irrigation, and maintenance. The following is the agricultural system in the prereform era.

At this time, farmers tend to plant a lot of corn and cassava. Plant care does not need to use fertilizers. It only relies on forest soil conditions that are still natural and fertile. The irrigation system at this time still relies on rain-fed water. The main plant recommended by Perhutani is the type of sea sengon. Saigon is recommended because it has a reasonably high selling value and its maintenance is relatively easy when combined with the care of plants understands. However, this did not last long when the sengon plants began to be attacked by pests and gall rust disease. This pest causes the wood of the sengon tree to rot and then causes the tree to fall.

This disease is caused by the fungus Uromycladium tepperianum, which attacks the stems, twigs, and leaves of sengon [21]. $U$. tepperianum results in decreased productivity because it will cause the death of young trees and decrease the selling value of mature sengon cut wood when sold.

Forest society which manages land in the Perhutani area, does not rule out the possibility of owning compounding land. During the prereformation period, most stand plants in the Perhutani area and compounding land were sengon.

Cases of illegal logging are prevalent because the wood between these locations has the same type, making it challenging to identify where the wood came from. In addition, forest society is currently subject to a profit-sharing tax levy set by Perhutani, which is $75 \%$ Perhutani and $25 \%$ of the community.

\subsubsection{Land Management Patterns during the Reformation Era}

Forest society started to plant horticultural commodities, namely vegetables and fruit, as plants understand. However, some farmers also still grow cassava and corn. In addition, the main types of plants that were initially the majority of sengon were replaced by pine and mahogany types [22]. The replacement of the plant species was carried out in stages due to the attack of pests and rust disease.

The transformation of agricultural activities at this time showed a high orientation towards efforts to increase crop productivity [23]. This is evidenced by applying organic fertilizers from chicken manure and chemical fertilizers that are used regularly.

In addition to using chemical fertilizers, Forest society has also begun to practice chemical pesticides in maintaining plants understanding. The transformation of the Forest society farming system has also begun to recognize black and white plastic mulch as one of the agricultural technology efforts to increase productivity. However, the use of plastic mulch in forest areas is included in the prohibition by Perhutani because it is considered to damage the function and environment of the original forest.

Perhutani decided to change the types of stand plants to pine and mahogany. The selection of pine species is adjusted to the natural conditions which have been degraded due to rampant illegal logging. Perhutani considers considering the conditions and characteristics of pine plants that can grow in such areas. This is supported by Sadili's (2015) research in Wahyuno et al. [24], which states that Perhutani plants the pine trees because they have high prospects even though they are planted in degraded and nutrient-poor areas.

While choosing mahogany trees and others is related to plant regulations, homogeneous wood species usually characterize production forests. In order not to be too homogeneous, Perhutani issued a regulation on the existence of border plants (surrounding the production forest area), filler plants (in between plants) and ornamental plants (in between plants) in production forests.

The grass is often used as personal fodder by the Forest society. Non-timber forest products used by Perhutani are pine resin and pine seeds. This pine sap will later be processed into turpentine oil which will later become one of the raw materials in the health and building industry.

The transformations that occur in forest products affect the employment opportunities of Forest society as well. Forest society has the opportunity to work for Perhutani as a farmer tapping pine resin. 
The results of the tapping will be valued at IDR $3,500 / \mathrm{kg}$ by Perhutani.

Forest society is given socialization of tapping techniques before working in the field. However, not all Forest societies are willing to be eavesdroppers. Forest society is allowed to participate in tapping or only managing arable land.

Perhutani issued a program that seeks to improve the welfare of forest village communities, known as PHBM (Community Forest Management). PHBM and LKDPH are a bridge between Perhutani and the community and the community and Perhutani in sustainable forest management.

\subsubsection{Post-Reformation Land Management Pattern Planting and Maintenance}

The transformation of planting and maintenance patterns from the New Order era-early reformationpresent can be described in the following table.

Table 2. Agricultural System Transformation from the New Order-Reform-Present Period

\begin{tabular}{|c|c|c|c|}
\hline \multirow{2}{*}{ Cultivation Activities } & \multicolumn{3}{|c|}{ Transition period } \\
\hline & New Order Era & Reformation Era & New Era \\
\hline $\begin{array}{l}\text { Soil Cultivation and } \\
\text { Fertilization }\end{array}$ & $\begin{array}{l}\text { The soil is not processed } \\
\text { too much, only using } \\
\text { organic fertilizer from } \\
\text { litter. }\end{array}$ & $\begin{array}{lcr}\text { Use of } & \text { organic } & \text { fertilizers } \\
\text { derived } & \text { from } & \text { chicken } \\
\text { manure } & \text { and } & \text { inorganic } \\
\text { fertilizers } & & \end{array}$ & $\begin{array}{l}\text { The use of organic fertilizers } \\
\text { derived from chicken manure } \\
\text { is starting to decrease, replaced } \\
\text { by organic fertilizers derived } \\
\text { from goat or cow manure. }\end{array}$ \\
\hline Commodity & $\begin{array}{l}\text { Types of commodities } \\
\text { between farmers follow } \\
\text { each other. }\end{array}$ & $\begin{array}{l}\text { Types of commodities } \\
\text { starting to grow horticultural } \\
\text { crops (vegetables and fruit) }\end{array}$ & $\begin{array}{l}\text { Types of horticultural } \\
\text { commodities and plantation } \\
\text { crops such as coffee }\end{array}$ \\
\hline Irrigation & Relying on rain-fed water & Relying on rain-fed water & $\begin{array}{l}\text { There are water pipe } \\
\text { installations for farming at } \\
\text { several points }\end{array}$ \\
\hline Disease Pest Control & $\begin{array}{l}\text { Pest and disease control is } \\
\text { only done mechanically. }\end{array}$ & $\begin{array}{l}\text { Pest and disease control is } \\
\text { carried out mechanically and } \\
\text { chemically. }\end{array}$ & $\begin{array}{l}\text { Pest and disease control is } \\
\text { done predominantly chemically } \\
\text { and mechanically }\end{array}$ \\
\hline
\end{tabular}

Source: Data processed by researchers (2021)

Agricultural transformation in land management and use of fertilizers by Forest society in Bambang Village is now starting to show significant developments. This is evidenced by the Pesangggem, which can analyze the optimal needs of plants together by minimizing expenditure in the form of fertilizers.

\subsubsection{Processing and Marketing of Forest Products}

The transformation of forest products from the New Order era to reformation to the present has undergone several changes in the types of commodities [14]. Therefore, in 2017 and above,
Bambang Village received and proposed several planting cooperation programs with the KLHK (Ministry of Environment and Forestry) to affect the types of commodities cultivated by the Forest society, as shown in Table 3.

Based on the table above, it can be concluded that the transformation of Forest society yields was the addition of various types of annual fruit crops from forest products during the initial reformation period. This collaboration program is carried out by forest village communities, including LKDPH, Forest Farmers Groups, and Gapoktan members. 
Table 3. Forest Product Transformation from the New Order - Reformation Era - Present

\begin{tabular}{|l|l|l|}
\hline \multirow{2}{*}{ Transition Period } & \multicolumn{1}{|c|}{ Forest products } \\
\cline { 2 - 3 } New Order Era & $\begin{array}{l}|c| \\
\text { Sign Wood } \\
\text { Firewood } \\
\text { Wood Charcoal }\end{array}$ & $\begin{array}{l}\text { Corn } \\
\text { Cassava }\end{array}$ \\
\hline \multirow{5}{*}{ Reformation Era } & $\begin{array}{l}\text { Sengon wood (decreased) } \\
\text { Pine Wood }\end{array}$ & Pine Sap \\
& Mahogany & Pinecone \\
& Re wood & Corn \\
& Firewood & Cassava \\
& Wood Charcoal & Grass \\
\hline \multirow{3}{*}{ Present } & Pine Wood & Horticultural Crops (chilli, long beans, coffee) \\
& Mahogany & Pine Sap \\
& Re wood & Pinecone \\
& Firewood & Corn \\
& Wood Charcoal & Cassava \\
& & Grass \\
\hline
\end{tabular}

Source: Data processed by researchers (2021)

\subsubsection{Perhutani Cooperation Policy with Forest Society and Institutions}

The transformation of Perhutani's cooperation policy with institutions and Forest society can be described as follows (Figure 1). The transformation in the post-reform period or the present can be seen from changes in management subjects such as the change in the management of LKDPH, the change of the Perhutani Mantri every four years, as well as the Perhutani foreman. This change in management certainly has an impact on the joint management of forests. Managers nowadays often apply for subsidies for fertilizers or seeds to restore and maintain forest sustainability. In addition to physical assistance, managers also try to fund regional institutions such as BPDAS or Perhutani. As for certain conditions supporting the submission, in the process, the forest village community formed an institution, namely, the KTH (Forest Farmers Group) Tani Makmur.

Several special rules distinguish the PHBM policy and the two versions of the social forestry policy relating to the rights and obligations of the Forest society or forest village community,

\section{New Oder Era}

- Cooperation in the form of a maximum management contract closing period of 4 years

- No existence of the forest society

\section{Reformation Era}

- Cooperation in the form of joint management through PHBM

- The establishment of the LKDPH institution as a bridge to Perhutani

\section{Present (2019-2021)}

- Cooperation in the form of joint management through PHBM and Social Forestry

- Establishment of KTH institution (Forest Farmers Group)

Figure 1 Transformation of Perhutani's Cooperation Policy with MDH from the New Order Period - Reformasi - Present including: 
Table 4. Differences in PHBM and Social Forestry Policies

\begin{tabular}{|c|c|c|}
\hline \multirow{2}{*}{ PHBM } & \multicolumn{2}{|c|}{ Social Forestry } \\
\hline & P.83 & P.39 \\
\hline $\begin{array}{l}\text { 1. There are no written rules } \\
\text { for the management right }\end{array}$ & $\begin{array}{l}\text { Land management rights up to } 35 \\
\text { years }\end{array}$ & $\begin{array}{l}\text { Land management rights up to } 35 \\
\text { years }\end{array}$ \\
\hline $\begin{array}{l}\text { 2. There is no certificate of } \\
\text { management right on } \\
\text { arable land. }\end{array}$ & $\begin{array}{l}\text { Each Forest society has a certificate of } \\
\text { management rights that explains the } \\
\text { year of management, the location of } \\
\text { the plots, and the private information } \\
\text { of the Forest society. }\end{array}$ & $\begin{array}{l}\text { Each Forest society has a certificate } \\
\text { of management rights that explains } \\
\text { the year of management, the location } \\
\text { of the plots, and the private } \\
\text { information of the Forest society. }\end{array}$ \\
\hline $\begin{array}{l}\text { 3. There is no cooperation } \\
\text { regarding savings and } \\
\text { loan/capital allowances. }\end{array}$ & $\begin{array}{l}\text { There is cooperation with Bank BNI } \\
\text { as a partner providing savings and } \\
\text { loan/capital allowances (requirements } \\
\text { for a certificate of management } \\
\text { rights) }\end{array}$ & $\begin{array}{l}\text { There is cooperation with Bank BNI } \\
\text { as a partner providing savings and } \\
\text { loan/capital allowances (requirements } \\
\text { for a certificate of management } \\
\text { rights) }\end{array}$ \\
\hline $\begin{array}{l}\text { 4. MCC regulates Profit- } \\
\text { sharing }\end{array}$ & $\begin{array}{l}\text { Profit-sharing is regulated by } \\
\text { KulinKK (Recognition of Protection } \\
\text { of Forest Cooperation) such as PKS. }\end{array}$ & $\begin{array}{l}\text { Mandatory profit sharing or sharing } \\
\text { to Perhutani of } 10 \% \text { of the profit of } \\
\text { forest products in one year }\end{array}$ \\
\hline $\begin{array}{l}\text { 5. Maintain and care for } \\
\text { standing plants in the } \\
\text { forest }\end{array}$ & $\begin{array}{l}\text { Maintain and care for standing plants } \\
\text { in the forest }\end{array}$ & $\begin{array}{l}\text { Environmental submission } \\
\text { requirements if: } \\
\text { a. Number of stands }<10 \% \text { in forest } \\
\text { b. Obliged to make } 50 \% \text { of forest } \\
\text { area planted with trees or wood } \\
\text { plants (30\% MPTS (Multipurpose } \\
\text { Tree Species) }+20 \% \text { crops) }\end{array}$ \\
\hline
\end{tabular}

Source: Data processed by researchers (2021)

Based on the description of the table above, when related to the current conditions in Bambang Village, the forest village community (forest society and village institutions with interests) still have not implemented social forestry policies. Field results show that both LKDPH, KTH, or Forest society are still foreign or not aware of the existence of this policy. However, according to the statement from the Mantri of Perhutani KRPH Bambang Utara in an interview on March 3, 2021, if Bambang Village plans to apply for a social forestry policy, the best option is to use the Social Forestry policy P.83. This is because so as not to change the condition of the forest by forcing it to meet the prerequisites for the number of stands $<10 \%$. If that happens, it is the same as allowing the community to clear the forest. In addition, the cost of sharing can be said to be higher in the P.39 policy compared to P.83 and even the PHBM policy itself.

\subsection{Adaptation of Forest society Land Transformation in Forest Area}

Adaptation can be interpreted as opportunities, effects of social and cultural practices that are unconsciously able to influence individuals. Adaptation is considered an effort to maintain living conditions in the face of change [25]. Not just a response to a phenomenon, adaptation influences how individual strategies follow the change. The message response is grouped into three areas of transformation theory, include:

a. The personal field, related to the views, patterns of thinking, and intentions of the Forest society covering the activities of planting, maintaining, and marketing forest products;

b. Practical field, related to the actions and behavior of the Forest society in the activities of planting, maintaining, sharing, and marketing forest products;

c. In the political field, it is related to the system and rules followed by the Forest society during farming in the forest area arable land.

\subsection{The Impact of Forest society on Post- Reform Adaptation Patterns}

The adaptation pattern of forest village communities, including Forest society, LKDPH, and $\mathrm{KTH}$, to the transformation of arable land management in forest areas, tends to have a positive impact. However, forest society in its development period has more positive impacts. This is due to the 
development of technology and the ease of access to forest management in Bambang Village.

\subsubsection{Open Access to Development and Empowerment Programs}

Access to community development and empowerment programs can be proven from the level of activity of LKDPH and KTH. Institutions with MDH have worked together in applying for funding or subsidized assistance for the past few years. These activities also have the impact of opening up opportunities for other parties such as academics or private companies who intend to establish forest conservation and rehabilitation with the community.

\subsubsection{Increasing Alternative Livelihoods for Forest Community Masyarakat Daerah Hutan $M D H$}

Forest society or communities around the forest do not rule out the possibility of more varied livelihoods. This can be proven from the pine tree planting program by Perhutani, opening up opportunities for Forest society to have additional sources of income from tapping pine trees. Based on researchers' observations in the field, it was found that such as motorcycle taxi services with trail bikes, UMKM stalls around the village, and Pokdarwis empowerment program managers (Tourism Awareness Group), KTH, and LKDPH.

\subsubsection{Forest Environmental Conservation}

The existence of the UP-UPSA program as a form of initial pilot and assistance is one of the advantages of environmental conservation. The future CCCD project will focus on planting and improving springs, the benefits of which will be felt along the watershed. This will also impact flora and fauna in the forest area so that it is maintained. In addition, cultivation activities can be integrated and minimize the occurrence of natural disasters.

\section{CONCLUSIONS}

The pattern of land management for forest areas in the New Order until the reformation stipulated profit sharing of $75 \%$ Perhutani and $25 \%$ of the community, limited to a maximum of 3 years. Timber forest production plants are mostly pine and mahogany. It is starting to focus on fruit trees, organic farming, and Perhutani is not subject to profit sharing. The Social Forestry policy program is considered relevant to the needs of farmers. The impact of the transformation of management is opening access to programs for empowerment and conservation of the forest environment. This research hopes that various parties in forest management are open, honest, and aware of preserving the environment through environmental conservation programs.

\section{ACKNOWLEDGMENTS}

The author would like thank you very much for Lembaga Penelitian dan Pengabdian Masyarakat Universitas Brawijaya (LPPM UB) for its support for the research and writing of this article. With the support in the form of moral and material, this activity can be completed properly.

\section{REFERENCES}

[1] I.V. Muralikrishna, V. Manickam, Natural resource management and biodiversity conservation, In Environmental Management, Elsevier, 2017, pp. 23-35. https://doi.org/10.1016/b978-0-12-8119891.00003-8

[2] Iskandar, S.M. Daud, H. Djuhaendah, I. Nurlinda, Kebijakan perubahan kawasan hutan, dalam pengelolaan berkelanjutan (C. S. D. I. Wilson Nadeak (Koordinator), Tuhpawana P. Sendjaja Fatimah Djajasudarma, Benito A. Kurnani Denie Heriyadi, Wahya (ed.)). UNPAD PRESS, 2011 [In Indonesian]

[3] KLHK, Status hutan dan kehutanan indonesia, In Kementerian Lingkungan Hidup dan Kehutanan RI, 2018 [In Indonesian]

[4] BPS, Angka deforestasi netto indonesia di dalam dan di luar kawasan hutan tahun 20132018 (Ha/Th). Bps.Go.Id, 2018. https://www.bps.go.id/statictable/2019/11/25/2 081/angka-deforestasi-netto-indonesia-didalam-dan-di-luar-kawasan-hutan-tahun-20132018-ha-th-.html [In Indonesian]

[5] Asosiasi Pertambangan Batubara Indonesia, Gelar Gerakan Pemulihan DAS, KLHK dan CCCD tanam 3.000 pohon di Malang, APBIICMA, 2019. http://www.apbiicma.org/news/2030/gelar-gerakan-pemulihan- 
das-klhk-dan-cccd-tanam-3000-pohon-dimalang [In Indonesian]

[6] F. Emilia, Pengelolaan sumber daya alam berbasis masyarakat dalam upaya konservasi daerah aliran sungai (Studi Kasus Desa Keseneng, Kecamatan Sumowono, Kabupaten Semarang), Universitas Diponegoro, In Plastic and Reconstructive Surgery, vol. 104, 2013. https://doi.org/10.1097/00006534-199907000$\underline{00071}$ [In Indonesian]

[7] Yunasfi, Penerapan sistem agroforestry pada program penghijauan dan konservasi tanah (Kegiatan agroforestry di luar kawasan hutan). USU Repository, 28, 2018 [In Indonesian]

[8] J.A. Wijaya, Pengelolaan Hutan Bersama Masyarakat (PHBM) perum perhutani $\mathrm{KPH}$ cianjur, 2021. https://arocki.com/pengelolaanhutan-bersama-masyarakat-phbm-perumPerhutani-kph-cianjur/ [In Indonesian]

[9] M. Pelling, Adaptation to climate change: From resilience to transformation, In Adaptation to Climate Change: From Resilience to Transformation (berilustra), Routledge, 2010. https://doi.org/10.4324/9780203889046

[10] Tim Project Cifor dan Fahutan UGM, Pengelolaan Hutan Bersama Masyarakat (PHBM): Kolaborasi antara masyarakat desa hutan dengan perum perhutani dalam pengelolaan sumberdaya hutan di Jawa, Uni Eropa, CIRAD, CIFOR, UGM, Perum Perhutani, 4, 2007 [In Indonesian]

[11] K. O'Brien, $\mathrm{K}$, the courage to change: Adaptation from the inside-out, In Successful adaptation to climate change: linking science and policy in a rapidly changing world, 2013 . DOI: https://doi.org/10.4324/9780203593882

[12] R.W. Kates, W.R. Travis, T.J. Wilbanks, Transformational adaptation when incremental adaptations to climate change are insufficient, Proceedings of the National Academy of Sciences of the United States of America, vol. 109(19), 2012, pp. 7156-7161. DOI: https://doi.org/10.1073/pnas.1115521109

[13] Perhutani.co.id, Sejarah perum perhutani, Perhutani, 2020. https://Perhutani.co.id/tentang-kami/sejarahperum-Perhutani/ [In Indonesian]

[14] K. Ismanto, M. Huda, C. Maulida, Transformasi masyarakat petani mranggen menuju masyarakat industri, Jurnal Penelitian, vol. $\quad 9(1), \quad 2013.2 \quad$ DOI:

https://doi.org/10.28918/jupe.v9i1.129 [In Indonesian]

[15] T. Subarna, Faktor yang mempengaruhi masyarakat menggarap lahan di hutan lindung: Studi Kasus di Kabupaten Garut Jawa Barat. Jurnal Penelitian Sosial dan Ekonomi Kehutanan, vol. 8(4), 2011, pp. 265-275. DOI: https://doi.org/10.20886/jsek.2011.8.4.265-275 [In Indonesian]

[16] Pemerintah Desa Bambang, Laporan Pertanggungjawaban Pemerintah Desa Bambang Tahun 2019, 2020 [In Indonesian]

[17] J.W. Creswell, Penelitian kualitatif \& desain riset, In Mycological Research, 1990 [In Indonesian]

[18] Sugiyono, Metode Penelitian Kuantitatif, Kualitatif dan R\&D. PT Alfabet, 2016.

[19] R. Octaviani, E. Sutriani, Analisis Data Dan Pengecekan Keabsahan Data, 2019. DOI: https://doi.org/10.31227/osf.io/3w6qs [In Indonesian]

[20] JW.D. usuf, I. Anggraeni, serangan boktor (xystrocera festiva pascoe) dan karat tumor (uromycladium tepperianum (sacc.) mcalpine) pada sengon (falcataria mollucana (miq.) di perkebunan teh ciater, Jurnal Sains Natural, vol. 8(2), no. 59, 2018. DOI: https://doi.org/10.31938/jsn.v8i2.119 [In Indonesian]

[21] A.P. Septiadi, B. Istiaji, A. Munif, S.K. Lina, W. Gustiah, L.H. Yuli, A. Mu'iz, A. Buchori, Eksplorasi agen pengendali hayati karat puru sengon (uromycladium tepperianum) di kabupaten pekalongan (exploration for biological control agent of sengon gall rust disease (uromycladium tepperianum) in pekalongan), Jurnal Pusat Inovasi Masyarakat, vol. 1, 2019, pp. 79-86 [In Indonesian]

[22] Pratiwi, M.E. Hartoyo, B.H. Narendra, D, I. W. S, Kesesuaian Jenis pohon pada lahan kritis di sub das lesti, Jawa Timur, Jurnal Penelitian Hutan Dan Konservasi Alam, 11(2), 2014, pp. 183-204.

DOI: https://doi.org/10.20886/jphka.2014.11.2.183204 [In Indonesian]

[23] H. Gosnell, N. Gill, M. Voyer, Transformational adaptation on the farm: Processes of change and persistence in transitions to 'climate-smart' regenerative agriculture, Global Environmental Change, 
vol. 59, 101965, 2019. DOI: https://doi.org/10.1016/j.gloenvcha.2019.1019 65

[24] D. Wahyuno, D. Astuti, Elfahmi, E.G. Lestari, G. Semiadi, I. Saskiawan, Nurainas, R. Gustiano, W.A. Qosim, Berita Biologi LIPI, Jurnal Ilmu-Ilmu Hayati, vol. 14(3), no. 16, 2015 [In Indonesian]

[25] A. Mahmud, Adaptasi sebagai strategi bertahan hidup manusia Amir Mahmud, Ar-Risalah, vol. 17(1), 2016, pp. 51-62 [In Indonesian] 